\title{
Mobile Learning: A New Approach to College English Teaching
}

\author{
Hui Yan ${ }^{1, a}$ \\ ${ }^{1}$ Xi'an Peihua University, Xi'an City, Shaanxi Province, China, 710125 \\ a email:
}

Keyword: Mobile Learning, College English, Characteristic, Development Strategy

\begin{abstract}
Mobile learning, a new pattern of learning which comes after E-learning and D-Learning, is based on electrical mobile devices. Therefore, it has a lot of advantages that can be well complementary with traditional model of teaching in class. Based on the author's teaching experience, this paper first analyzed the characteristics of mobile learning, then studied the two kinds of college English mobile learning model, finally put forward the strategies for the implementation of college English mobile learning model. Practice shows that the new teaching model can enhance students' study initiative and increase their English proficiency.
\end{abstract}

\section{The Characteristics of Mobile Learning}

As the name suggests, mobile learning refers to freestyle learning with no need to study in a fixed place, but can study at any place and at any time. Of course, mobile learning can not be separated from the network and wireless terminal equipment. At the same time, mobile learning must also have a wealth of learning resources and the interaction between people. The ubiquitous network, various types of communications equipment and massive mobile learning resources make the learner's learning process become more free, convenient and efficient. This novel and efficient way of learning breaks the time and space limitation of the learners, and provides a new way for the reform of college education and teaching.

\section{Analysis of College English Mobile Learning Model}

Online college English mobile learning model. (1) Vocabulary learning based on short message, email, class QQ group and WeChat group: Teachers send students a group of 4 new words by WeChat, and the students are required to use their mobile phones to learn the pronunciation of the word and to understand its usage. Next day, the teachers will announce 4 new words exercises in the WeChat group to test the students' learning effect, and strengthen the students' ability to use words. The new word exercises and answers will be sent simultaneously to the class QQ group every day, and check on the classroom to ensure that students' autonomous learning has achieved a complete success. (2) Listening and reading learning based on class QQ group and WeChat group: Teachers selects a short listening material and a short reading material related to the subject matter of the current curriculum from VOA, BBC or other English website resources to send them to the class QQ group and WeChat group, in order to facilitate the students to have the destination to study. In order to urge students to learn English, for some listening materials, it can repeat the words in class, then write a summary to feedback to the teacher through the QQ or WeChat and other convenient ways. (3) Oral English learning based on class QQ group and WeChat group: Oral expression is the key way to output the students' information, and it is very important in the learning process. In order to give students more opportunities to create more English practice, teachers can 
use the QQ group, WeChat Group to establish an English corner platform. In this platform, English will be the only communication language, so the students can study in the whole English environment together with the exchange. In an atmosphere of mutual promotion, students' ability to express their spoken English is increasing. In order to improve the ability of oral expression, the way of speech communication is more respected. In the QQ group and WeChat group, teachers are playing the role of organizers and sponsors. In order to encourage everyone to participate in interaction, the teachers should timely feedback on students' participation. (4) Writing training based on Composition Platform: At present, the country's largest English writing platform -

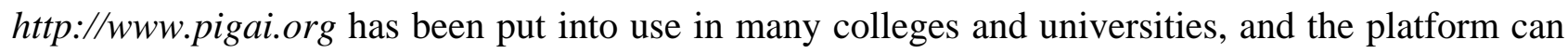
be submitted to the students in a timely manner to give scores, reviews and comments.According to the author's observation, some students modify the composition according to the correction of the comments to get their own satisfaction scores.

Offline college English mobile learning model. (1) Using stored resources to learn: Using mobile features of tablet PC, electronic reader and smart phone, the multimedia courseware, video, video and other digital content are stored on mobile devices, to help students achieve the learning. At the same time, pull the content of teaching materials and related content into the mobile phone to enrich the mobile learning resources, increase the utilization rate of resources and quickly update the contents of the textbook. According to the author's teaching observation, the students are very interested in the learning mode that is not limited by the network conditions. (2) Using mobile phone application software to learn: With the popularity of smart phones and tablet PCs in the hands of students and the increasing use, they are more and more interested in the application of software on the mobile platform. Essentials by Accela Study is a useful App that can improve the foreign language learning efficiency. The APP has a word card function, support for voice testing, not only can help memory vocabulary, but also can correct pronunciation. At the same time, all kinds of English Chinese or Chinese English dictionary software in mobile phone is very convenient and good helper for English learning.

\section{Strategies for the Implementation of College English Mobile Learning Model}

Improving teaching content. To make full use of the psychology of modern information technology and Internet technology, teachers should encourage students to use mobile communication devices to learn English, instead of just confined to the content of the text. The author thinks that English teaching should go out of the traditional teaching, expand the content of English learning out of the classroom. For example, teachers can collect the classic English original movies, which are related to the teaching materials, and recommend it to students after class. Students may download movies to mobile devices, at the same time, teachers can also launch a discussion on the film by class QQ group, WeChat group. Teachers can design a few problems from the film content, character, cultural differences and other aspects, give some tips to guide students to discuss, which will not only train the students' ability to understand English and improve their English expression ability, but also stimulate their divergent thinking.

Enriching teaching methods. At present, multimedia has become a widely used teaching equipment in College English teaching, which has played a positive role in stimulating students' interest and improving their learning efficiency. The mobile computing devices used in mobile learning must be able to effectively present the learning content and provide two-way communication between teachers and students, and only multimedia technology is still far from meeting the needs of mobile learning. In the mobile learning model discussed in the previous, the author repeatedly referred to the QQ group which is undoubtedly a good platform for teachers and 
students to exchange learning situation, so we can make full use of English teaching network to urge students to learn online. Supervising the students' participation in the teaching network, such as online time, browsing the resources, participating in the discussion and so on. For the master of these situations, the teacher can publish it monthly in the class QQ group, in order to stimulate the enthusiasm of students' mobile learn.

Changing teacher's role. In the mobile learning, in order to improve the level of mobile learning services to ensure the effectiveness of learning, teachers also need to play the role of researchers and designers in addition to play a good role in the traditional role. First of all, on the effectiveness of mobile learning, teachers should first analyze the individual differences of students, including learning attitude, learning ability, learning methods, professional characteristics and time management, etc., to lay the foundation for the personalized design, guidance and service in the process of mobile learning. Second, on the basis of the study of students' differences, teachers should design course teaching and learning objectives, to do a good job of mobile learning designers according to the specific needs of students, learning ability and professional characteristics. In view of the characteristics of mobile learning, people's attention in the mobile situation is very easy to be disturbed. Therefore, the mobile learning resources must be selected for spare time to learn the material. Based on my learning experience, Android mobile phone system comes with a word APP - Youdao Dict, which is very suitable for mobile learning language materials. Due to the larger flow, it is suitable for use in the case of Wi-Fi. At the same time, mobile learning is very flexible and random, so the information content must be small, fragmented, and modular. The micro class with short teaching time, less teaching content and specific content is very popular, so it is very suitable to be used as a learning resource for mobile learning. Third, for students with little independent learning ability, the teacher should adopt various incentive mechanisms, such as the usual performance category of mobile learning included in the final review will stimulate students to participate actively in the mobile learning to guide students to achieve the learning objectives, and tracing the use of information technology, guidance and evaluation, to move the guidance of learning.

Innovating evaluation mechanism. The evaluation of students' learning effect is not only an important measure to test the quality of students' education quality, but also a necessary way to supervise and train the students to study hard and pay attention to learning. Mobile learning mode needs to reform the evaluation mechanism to make the mobile learning and traditional learning be combined more organically. Because mobile learning does not have a fixed learning place, it is difficult for teachers to control the students' learning time, learning content and quality. Strive to make students be their own masters in the entire mobile learning evaluation process, to make the students find out their learning progress and defects, to understand the direction of the efforts, so this will make up for the lack of control of teachers, improve the effect of mobile learning, making it a powerful complement to traditional learning. Combining the original basic evaluation of student's mobile learning with the growth of the students, on one hand, teachers can fully understand the whole process of the change of students' mobile learning, on the other hand, the progressive student is encouraged through the longitudinal comparison of the status of mobile learning. By this way, it will not only increase the students' awareness of their mobile learning situation, but also stimulate their enthusiasm and morale in the comparative education, to achieve the harmonious unity of evaluation and learning.

\section{Conclusion}

The development of communication technology, the advancement of digital process, the 
extension of modern technology education, the subjective demand of college students' English learning and the objective need of college English teaching reform make a contribution to the mobile learning mode, and this learning model will have a far-reaching impact on the improvement of college English teaching. Of course, teachers should make efforts in teaching methods, teaching resources, the conversion of teachers' roles and the establishment of evaluation mechanism from the traditional fixed teaching to a new type of mobile teaching. Only in this way can the college English mobile learning model be a better way for students to learn English.

\section{References}

[1] Xue Jianqiang. Research on the construction and development of College English mobile learning model [J]. Experimental Technology and Management, 2014,03:176-179.

[2] Shao Baisheng, Zhu Ling. Mobile learning of College English based on smart phone [J]. Journal of Jilin College of Education (early), 2014,07:42-43.

[3] Bao Songbin. A new model of College English teaching and learning in the integration of mobile learning [J]. Laboratory Research and Exploration, 2013,04:144-147+151.

[4] Mao Ning. A study on mobile learning strategies of College English based on WeChat [J]. Chinese Audio Visual Education, 2016,03:136-140.

[5] Yang Lifang. The application of mobile learning in College English vocabulary learning [J]. Foreign Language Teaching and Learning, 2012,04:54-58.

[6] Wang Fei. Construction of College English mobile learning platform [J]. Journal of Shenyang Normal University (NATURAL SCIENCE EDITION), 2014,04:561-564. (in Chinese). 